精査機関と検診機関の連携から見た乳がん検診の実態と問題点 (4)

\title{
秋田県における精査機関と検診機関の連携から見た 乳がん検診の実態と問題点
}

\author{
秋田赤十字病院外科 ${ }^{1)}$, 秋田県乳がん検診委員会 ${ }^{21}$
}

\begin{tabular}{|c|c|c|c|c|c|c|c|}
\hline 鎌田 & 収一-12) & 佐志 & 隆士2) & 工藤 & 保 ${ }^{2)}$ & 中村 & 正明 ${ }^{2)}$ \\
\hline 片寄 & 喜久 ${ }^{2)}$ & 吉岡 & 知巳 ${ }^{2)}$ & 津田 & 晃 ${ }^{2)}$ & 石山 & 公—2) \\
\hline 佐藤 & 政弘 ${ }^{2)}$ & 西成 & 忍 ${ }^{2)}$ & & & & \\
\hline
\end{tabular}

\begin{abstract}
秋田県ではマンモグラフィ検診の導入が若干遅れたが, 最近では秋田県総合保健事業団 が行っているマンモグラフィ検診は充分な精度管理がなされている。产の成績は平成19年 度のがん発見率は0 $22 \%$,要精検率は8 .7\% ,精検受診率は約 $80 \%$,陽性反応的中度は3 $2 \%$ であり，全国平均とほぼ同じであった。要精検となった受診者に対してフィルムを持参さ せていなかったので, 短期間で 2 度マンモグラフィを撮影していた。また精査機関からの 報告のない割合か泫 $15 \%$ あった。この 2 点は今後の改善課題である。検診機関と精査機関 とが同じ場所で直接連携するため, 年 1 回のマンモグラフィ検診読影検討会を開催してい る。前年度の検診症例で教育効果が高いと判断された約50症例を検討し，この際に報告さ れた診断が妥当かも議論している。良性と報告されたが再検の結果, 最終診断か浮癌であ つた症例もあった。秋田県の精査機関30施設のうち，施設画像認定施設は11医療機関のみ であった。光のうち乳癌学会の専門医在籍は 4 機関, 認定医は 3 機関であった。数値には 表せないが, 精査機関のレベルの差はあるように考えられた。いずれ精査機関が備えるべ き条件の制定は精度管理の面からいって必然である。しかし，今すぐ精査機関の絞り込み を行うと, 少なくとも秋田県では実情に合わない可能性が高い。今後, 乳がん検診のさら なる飛躍を目指すためには精査機関の質の向上と検診機関と精査機関との密接な連携が必 要である。
\end{abstract}

Key words: 精度管理, 秋田県, マンモグラフィ検診, 精査機関, 連携

はじめに

乳がん検診の目的は死亡率の減少であることは いうまでもない。乥こを目指して，各方面から懸 命な努力がなされてきた。平成12年の厚生省(当 時)からの老健65号の通達 ${ }^{11}$ によりマンモグラフィ 検診が徐々に広まり，平成16年には厚生労働省が 「がん検診実施のための指針」を一部改正し(老

別冊請求先： † 010-1495 秋田市上北手猿田字苗代 沢222番地 1

秋田赤十字病院外科 鎌田収一

E-mail address : skamata@archosp-1998.com
老発第0427001号 $)^{2)}$, 現在は医療従事者のみなら ず検診受診者や一般の人々も乳がん検診の基本は マンモグラフィであることを理解するようになっ た。光して炎の精度管理に関しても，精度管理中 央委員会をはじめとする諸機関の努力により充分 に行われるようになった。いまや乳がん検診は他 蔵器の検診と比較しても, 勝るとも劣らない方法 として認知されている。

しかし, 乳がん検診機関の精度管理が進んでく ると新たな問題点が出てきた。検診で要精検と判 断された人々が受診する医療機関, 精査機関の精 度管理である。検診で極早期の乳がんを発見して も精査機関で的確な診断がなされなければ，受診 
者の利益とはならない。実際は乳がんでありなが ら，精査機関で充分な検査がなされず乳がんと診 断できなかった事例が聞こえてくる。この点を踏 まえて , 秋田県における現時点での精査機関と検 診機関の連携を検討し，乳がん検診の実態と問題 点を明らかにしたい。

\section{1. 秋田県の乳がん検診の成績}

秋田県の平成15年の乳がん検診の受診者数は 62 ,599名で, 受診率は25 .9\%と全国でもトップク ラスであった。しかし，㫕のうちマンモグラフィ 検診受診者は3 ,509名(5 .6\%)のみであり，これは 全国で最も低い県の一つであつた。关のため乳が
ん発見率も0 .08\%であり，全国平均と比べてかな り低值であっだ”。秋田県医師会は精度管理中央 委員会の指導のもとに, マンモグラフィ読影講習 会を 3 年連続開催した(現在は 2 年に 1 回)。また 平成16年度から検診車を 2 台購入し，29市町村が マンモグラフィ併用検診を実施し，さらに平成17 年度からは検診車を 4 台とし, 全市町村を網羅す ることが可能になった。

平成18年度の秋田県全体の受診率は15 .9\%で全 国平均からするとやや高いが, 東北のほかの県が 軒並み $20 \%$ 以上, 特に宮城, 山形が $30 \%$ を超えて いることを考えると低い受診率であった(表 11)。視触診検診の頃は受診率は25\%前後あったの

表 1-1. 秋田県のマンモグラフィ検診受診率

\begin{tabular}{r|r|r|r|r|r}
\hline & 対象者数 & \multicolumn{1}{|c|}{$\begin{array}{c}\text { 当該年度 } \\
\text { 受診者数 }\end{array}$} & $\begin{array}{c}\text { 前 年 度 } \\
\text { 受診者数 }\end{array}$ & $\begin{array}{c}\text { 2 年連続 } \\
\text { 受診者数 }\end{array}$ & \multicolumn{1}{c}{ 受診率 } \\
\hline 北海道 & 885,271 & 79,789 & 80,610 & 4,777 & 17.6 \\
青 森 & 225,946 & 33,062 & 33,503 & 6,143 & 26.7 \\
岩 手 & 269,142 & 37,360 & 37,786 & 5,322 & 25.9 \\
宮 城 & 468,142 & 78,169 & 76,930 & 3,774 & 321 \\
秋 田 & 231,658 & 19,727 & 18,009 & 893 & 15.9 \\
山 形 & 195,277 & 40,871 & 39,928 & 15,799 & 33.3 \\
福 島 & 300,411 & 37,183 & 35,016 & 1,715 & 23.5 \\
\hline 全 国 & $22,766,483$ & $1,631,811$ & $1,562,511$ & 266,346 & 12.9 \\
\hline
\end{tabular}

表 1-2. 秋田県の市町村別受診率

\begin{tabular}{|c|c|c|c|c|c|}
\hline 市町村 & 対象者数 & $\begin{array}{l}\text { 当該年度 } \\
\text { 受診者数 }\end{array}$ & $\begin{array}{l}\text { 前 年 度 } \\
\text { 受診者数 }\end{array}$ & $\begin{array}{l}2 \text { 年連続 } \\
\text { 受診者数 }\end{array}$ & 受診率 \\
\hline$A$ & 091 73 & 2,187 & 2,308 & - & 61 \\
\hline$B$ & 10,538 & 2,119 & 608 & 6 & 258 \\
\hline C & 36,658 & 3,390 & 3,268 & 3 & 182 \\
\hline$D$ & 19,754 & 408 & 374 & - & 4.0 \\
\hline$E$ & 4,487 & 641 & 422 & - & 23.7 \\
\hline E & 6,601 & 1,455 & 1,525 & - & 451 \\
\hline $\mathrm{F}$ & 11,607 & 623 & 863 & 2 & 128 \\
\hline G & 14,709 & 261 & 31 & - & 2.0 \\
\hline \multicolumn{6}{|c|}{ 途中省略 } \\
\hline $\mathrm{T}$ & 2,922 & 1,110 & 968 & - & 711 \\
\hline$U$ & 1251 & 329 & 306 & - & 508 \\
\hline V & 364 & 156 & 132 & - & 791 \\
\hline 全 県 & 231,658 & 19,727 & 18,009 & 893 & 15.9 \\
\hline
\end{tabular}


表 2. 秋田県総合保健事業団のマンモグラフィ検診の成績

\begin{tabular}{c|r|r|r|r|r|r|r|r|r}
\hline 年 度 & 受診者数 & $\begin{array}{r}\text { MM } \\
\text { 併用率 }\end{array}$ & 発見がん & $\begin{array}{r}\text { が ん } \\
\text { 発見率 }\end{array}$ & $\begin{array}{l}\text { 要精検 } \\
\text { 者 数 }\end{array}$ & 要精検率 & 精検数 & $\begin{array}{l}\text { 精 検 } \\
\text { 受診率 }\end{array}$ & $\begin{array}{c}\text { 陽性反応 } \\
\text { 的 中 率 }\end{array}$ \\
\hline 平成19年度 & 8,007 & $99 \%$ & 18 & $022 \%$ & 700 & $8.7 \%$ & 568 & $81.1 \%$ & $32 \%$ \\
平成18年度 & 7,608 & $97 \%$ & 22 & $029 \%$ & 758 & $10.0 \%$ & 680 & $89.7 \%$ & $32 \%$ \\
\hline
\end{tabular}

で, マンモグラフィ検診のシステムの構築に少し 難点があったと思われる。各市町村の受診率をみ ると，著明な差があった(表 1-2)。最も高い、村 では79 1\%なのに対して，最も低いG 市は2 $00 \%$ しかなかった。あまりに低い数值であり，電話で 問い合わせたが, 数值に間違いはなく，これまで は積極的にマンモグラフィ検診を行ってこなかっ たとのことであった。秋田県の人口の約 $1 / 3$ 弱 を占める秋田市は6 1\%と低迷している。人口の 少ない郡部に受診率の高い傾向があり，都市部に 低い傾向があった。受診率の向上は今後の大きな 課題である。

秋田県の検診機関には秋田県総合保健事業団， 厚生会があり，この中で秋田県乳がん検診委員会 が精度管理に深くかかわっている秋田県総合保健 事業団の乳がん検診について検討する。事業団は 秋田県の乳がん検診の約 $40 \%$ を担っている。

平成19年度の受診者数は8,007人，マンモグラ フィ併用率は99\%，がん発見率は0 22\%，要精検 率は8 .7\%，精検受診率は81\%，陽性反応的中度 は3 2\%であった(表 2)。要精検率が若干高く陽 性反応的中度が少し低いが, 本格的に比較読影が 始まったのが平成19年度からであり，徐々に改善 すると期待される。他はほぼ全国平均的な数值" であった。

秋田市ではこれまでの歴史的な経緯から施設検 診方式をとっている。施設検診の参加条件はマン モグラフィ読影認定 B 以上の医師の在籍である が , マンモグラフィ検診施設画像認定施設になつ ていない施設を受診する場合は，保健事業団のセ ンターでマンモグラフィを撮影し光れを自ら持参 し受診するため，同時併用 $\mathrm{B}$ にならざるを得な い。2 所の受診が必要になり, 受診者にとって かなりの負担になっている。これが秋田市の受診
率低迷の原因の一つと考えられる。もう少し受診 者の利便性を考慮するシステムへの変更が望まれ る。

秋田市以外の地域では検診バスによる集検方式 である。自動現像機が車載できないタイプのもの であり，必然的に分離併用 A で行っている。

\section{2. 検診機関から精査機関への連絡}

検診で要精検となった場合は受診者に通知がい き, 精查機関に検査を依頼する。产の際に精査機 関のリストが同封される。秋田県の精査機関は30 医療機関である。精査機関受診時に受診者が持っ ていくものはマンモグラフィ読影用紙(要精検の 理由, 所見部位, 比較読影の有無等はすべて記 載)，触診所見用紙，返信用用紙である。このと きに検診時のマンモグラフィのフィルム产のもの は持参しない。当然精査機関でもマンモグラフィ を撮影するので, 弚のため比較的短期間で 2 度マ ンモグラフィを撮影することになっていた。今後 改善すべき点と考える。

\section{3. 精査機関から検診機関への連絡}

精査機関からの返信は, 診断結果だけではなく 行った検査のすべての情報を書くことになってい る。送られてきた情報はすべて総合保健事業団で 整理され，データとして保存される。关のうちの 一部を表 3-1に示す。検診後 5〜6 ヶ月経過して もまだ精查報告がない場合は，検診受診者に精査 機関の受診の有無を問い合わせしている。もしも 精査機関を受診していた場合は, 精密機関の病院 長宛てに精検結果を問い合わせている。これでも 返信のない場合は報告なしとなる。精査機関から の報告の実数の一部を表 3-2 にあらわす。要精査 の受診者の $99 \%$ はリストの30医療機関を受診して 
表 3-1. 精査機関からの報告データ

\begin{tabular}{|c|c|c|c|c|c|c|c|c|}
\hline 検診番号 & カテゴリー & 精検結果 & 触診 & MMG & 超音波 & 細胞診 & 生検 & 精査機関 \\
\hline 720 & 5 & 乳がん & 1 & 1 & 1 & 1 & 1 & $E$ \\
\hline 386 & 5 & 乳がん & 1 & 1 & 1 & 1 & & $\mathrm{~F}$ \\
\hline 30203 & 5 & 乳がん & 1 & 1 & 1 & 1 & & $E$ \\
\hline 20030 & 5 & 乳腺症 & 1 & 1 & 1 & 1 & & G \\
\hline 52 & 4 & 乳がん & 1 & 1 & 1 & 1 & & K \\
\hline 159 & 4 & 乳がん & 1 & 1 & 1 & & & $\mathrm{~N}$ \\
\hline 50025 & 4 & 弚の他 & 1 & 1 & 1 & & & 0 \\
\hline 50044 & 4 & 乳がん & 1 & 1 & 1 & 1 & 1 & $E$ \\
\hline 50139 & 4 & 乳腺症 & 1 & 1 & 1 & & & E \\
\hline 35 & 4 & 弚の他 & 1 & 1 & 1 & & 1 & M \\
\hline 30091 & 4 & 乳がん & 1 & 1 & 1 & 1 & 1 & 0 \\
\hline 50414 & 4 & 乳がん & 1 & 1 & 1 & 1 & 1 & $E$ \\
\hline 395 & 4 & 乳腺症 & 1 & 1 & 1 & & & B \\
\hline 459 & 4 & 乳がん & 1 & 1 & 1 & 1 & & B \\
\hline 636 & 4 & 線維腺腫 & 1 & 1 & 1 & 1 & & B \\
\hline
\end{tabular}

表 3-2. 精査機関からの報告数および施設画像評価と専門医, 認定医の在籍の有無

\begin{tabular}{|c|c|c|c|c|c|c|}
\hline 2007年 & & \multicolumn{3}{|c|}{ 集検カテゴリー判定 } & & \\
\hline 精査機関 & 件数 & 3 & 4 & 5 & 施設画像評価 & 専門医の在籍 \\
\hline A & 79 & 79 & & & 認定 & 専門医 \\
\hline B & 45 & 39 & 6 & & & 不明 \\
\hline C & 39 & 36 & 3 & & 認定 & 専門医 \\
\hline D & 35 & 31 & 4 & & 認定 & 認定医 \\
\hline$E$ & 33 & 28 & 3 & 2 & 認定 & 専門医 \\
\hline $\mathrm{F}$ & 24 & 22 & 1 & 1 & 認定 & 認定医 \\
\hline G & 23 & 17 & 5 & 1 & & \\
\hline $\mathrm{H}$ & 22 & 19 & 3 & & & 認定医 \\
\hline I & 17 & 16 & 1 & & 認定 & 専門医 \\
\hline J & 15 & 13 & 2 & & & \\
\hline K & 11 & 10 & 1 & & & \\
\hline L & 8 & 8 & & & 認定 & \\
\hline M & 8 & 7 & 1 & & 認定 & 認定医 \\
\hline $\mathrm{N}$ & 8 & 7 & 1 & & & \\
\hline 0 & 7 & 4 & 3 & & 認定 & \\
\hline$P$ & 6 & 6 & & & & \\
\hline Q & 5 & 5 & & & 認定 & \\
\hline $\mathrm{R}$ & 5 & 5 & & & & 認定医 \\
\hline $\mathrm{S}$ & 3 & 3 & & & 認定 & \\
\hline
\end{tabular}

いた。最終的に精査機関からの報告のない割合が 15\%あつた。

4. マンモグラフィ読影の精度管理

秋田県乳がん検診委員会はマンモグラフィ読影 
表 4-1. 本人へのフィードバック用個人成績 (一次読影)

\begin{tabular}{c|c|c|c|c}
\hline 医師コード & 一次読影件数 & 一次要精検数 & 一次要精検率 & 乳がん数 \\
\hline 24 & 504 & 10 & $1.98 \%$ & 0 \\
32 & 605 & 13 & $215 \%$ & 1 \\
27 & 463 & 13 & $2.81 \%$ & 1 \\
25 & 643 & 19 & $2.95 \%$ & 1 \\
22 & 765 & 31 & $4.05 \%$ & 3 \\
28 & 364 & 15 & $4.12 \%$ & 0 \\
21 & 805 & 37 & $4.60 \%$ & 1 \\
18 & 564 & 26 & $4.61 \%$ & 0 \\
19 & 514 & 26 & $5.06 \%$ & 2 \\
13 & 482 & 25 & $519 \%$ & 0 \\
20 & 627 & 33 & $5.26 \%$ & 0 \\
12 & 997 & 54 & $5.42 \%$ & 1 \\
46 & 696 & 44 & $6.32 \%$ & 1 \\
11 & 699 & 46 & $6.58 \%$ & 2 \\
31 & 667 & 45 & $6.75 \%$ & 3 \\
16 & 515 & 47 & $9.13 \%$ & 3 \\
\hline 合 & $90+910$ & 484 & $4.88 \%$ & 17 \\
\hline
\end{tabular}

表 4-2. 本人へのフィードバック用個人成績 (二次読影)

\begin{tabular}{c|c|c|c|c}
\hline 医師コード & 二次読影件数 & 二次要精検数 & 二次要精検率 & 乳がん数 \\
\hline 6 & 1,113 & 29 & $2.61 \%$ & 2 \\
8 & 1,162 & 37 & $318 \%$ & 2 \\
10 & 1,063 & 37 & $3.48 \%$ & 2 \\
1 & 1,338 & 52 & $389 \%$ & 2 \\
7 & 1,007 & 48 & $4.77 \%$ & 1 \\
3 & 1,155 & 69 & $5.97 \%$ & 5 \\
4 & 828 & 62 & $7.49 \%$ & 1 \\
\hline
\end{tabular}

が円滑に行われるようにマンモグラフィ読影委員 会を結成した。読影委員会は評価 $A$ が 7 〜 8 , B が15〜20人からなり, 実際の読影は A と B が ペアで1回50〜200症例を読影する。この読影委 員会の精度管理のため, 個人の要精検率等を本人 にフィードバックしている。また 2 年に 1 回 , 秋 田県医師会と精度管理中央委員会との共催によ る, マンモグラフィ読影講習会を開催することに なっている。平成19年度の評価 A，B の医師の個 人データを表に示す(表 4-1)。1 人あたりの読影 件数が光れほど多くはなく，感度，特異度等は算 出していないが, 要精検率や乳癌発見数を表にし
て，他の医師の個人名が特定できないようにコー ド化し, 読影本人がどの位置にあるかが分かるよ うにして，本人宛に郵送している。秋田市の医療 機関方式の要精検率も同樣に算出し，これも医療 機関に自分の位置が分かるように送付される。医 療機関方式の検診には読影評価 B 以上の医師の 在籍が参加条件にもかかわらず要精検率が $20 \%$ を 超える施設が数ヶ所あり，今後の検討課題であ る。

\section{5. 検診機関と精査機関との連携}

平成18年から読影医師および精査機関のレベル 


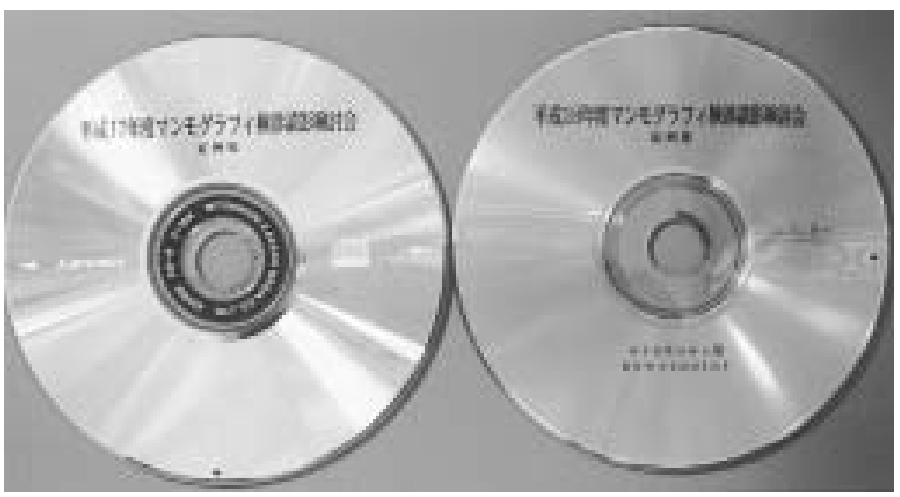

図 1. マンモグラフィ読影検討会の症例集

向上を目指し , 前年度のマンモグラフィの読影結 果を検討している。参加者は読影委員会会員およ び精査機関の医師である。対象症例は前年度の乳 癌症例全例，カテゴリー4,5の症例で教育効果が 高いと判断した症例，中間期乳癌である。前年度 の症例を事前に読影委員会の 4 人(マンモグラフ イ読影講習会の講師経験者)が精度管理中央委員 の助言を基に推奨カテゴリーを決定し，検討会当 日はマンモグラフィ読影講習会のグループ講習と 同じような形式で , 参加人数を 4 グループに分け 討論している。参加料は無料で, 検討時間は約 2 時間である。この会ではマンモグラフィの検討だ けではなく，前年度のマンモグラフィ検診のデー タ報告やマンモグラフィ読影時の要望またマンモ グラフィ読影検討会への要望等も話し合ってい る。この会で検討された，すべての症例は CD に データとして保存し(図 1), 検討会参加者に配布 している。また希望があれば精査機関にも送付し ている。

そして推奨カテゴリー決定の際に, 精査機関か らの報告と照合し，良性と報告されていても乳癌 の可能性が高い場合は, 精査機関に再検討をお願 いしている。症例 1 (図 2-1) は初めの返信が乳腺 症で再検後は乳頭腺管癌の報告であった。症例 2 (図 2-2) は，初めは光の他の報告であったが , 囊 胞内乳癌や充実腺管癌の可能性があると考え再検 をお願いしたが，兴の後の報告はなかった。症例 3 (図 2-3) は精査末受診であったが, 悪性の可能 性が高いので精検機関への受診を指導した。
6. 精査機関の精度管理

秋田県の精査機関は30医療機関であるが，精査 機関になるには現時点では参加条件はなく自己推 薦方式である。このうち施設画像評価認定施設は 11医療機関のみで, 19医療機関は認定されていな かった(表 3-2)。検診機関は当然施設画像認定を 取得しているので, 精査機関のほうの画像が劣つ ている場合も想定される。画像認定施設で且つ専 門医在籍は 4 医療機関，認定医は 3 医療機関であ った。また地域による差もあり，マンモグラフィ 検診施設画像認定施設かつ認定医以上が在籍して いるのはほとんどが秋田市であり，県北，県南は

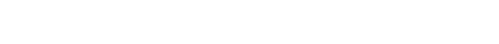

\section{7. 考 察}

導入が遅れた感のある秋田県のマンモグラフィ 検診も最近は精度管理がなされ，他県と遜色のな い検診が行われている。しかし受診率に関しては 満足できる数值ではない。今回の検討で各市町村 の受診率に著明な差があることが判明した。平成 10年にがん検診が一般財源化されてからは，受診 率を上げれば上げるほどその自治体の財政を逼迫 させるという奇妙なパラドックスが生まれてしま つた。平成18年 6 月に「がん対策基本法」5゙が成立 し，㚇の中でがんの予防および早期発見の推進が うたわれている。光して平成19年 6 月の「がん対 策推進基本計画」向では目標の一つにがん検診受診 率を50\%以上に引き上げることが明記されてい 


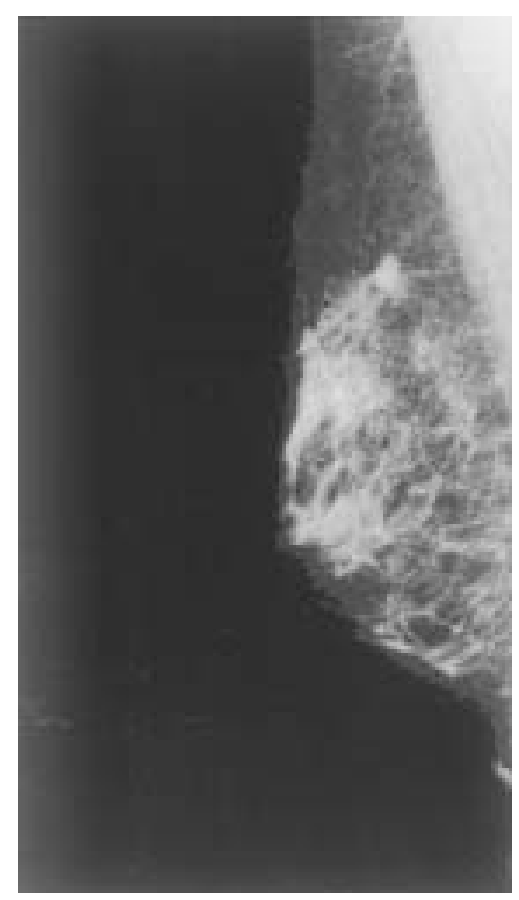

図 2-1. 悪性の可能性があり，精査機関に再検討を お願いした症例 . 最終診断は乳癌であった .

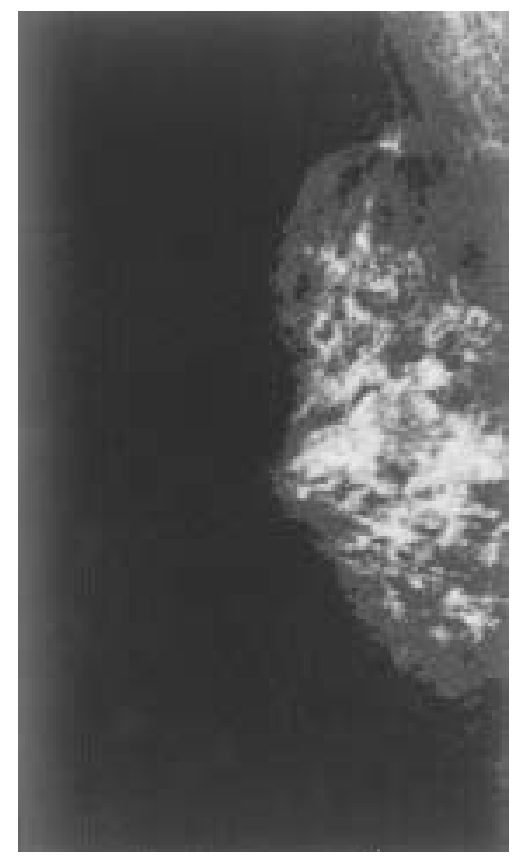

図 2-3. 精検未受診例 : 悪性の可能性が高いので, 受診者に精検を勧めた。

る。これを成功させるためには光れなりの財政支 援が必要なことは明白である。担当行政機関の䜭

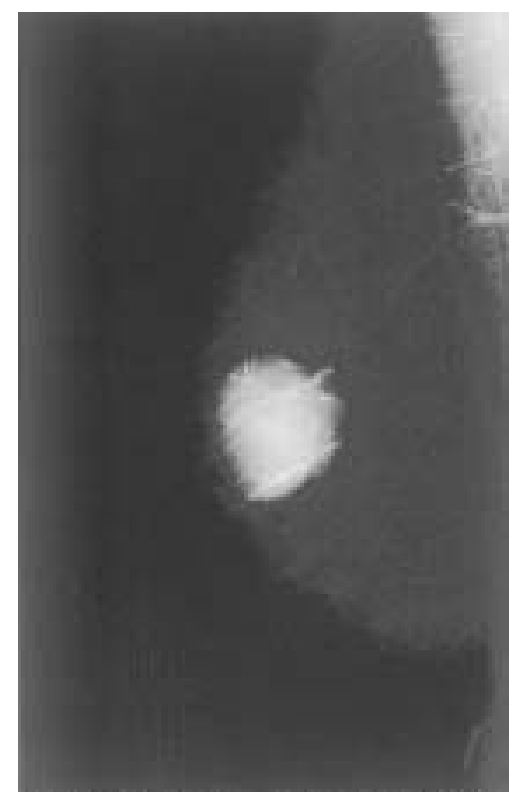

図 2-2. 悪性の可能性があり，精査機関に再検討を お願いした症例 . 最終診断は不明 .

智を結集して，弚の予算獲得が望まれる。

乳がん検診のシステムに関しては精度管理中央 委員会により, 講習会, 更新制度, 指導者講習 会 , 施設画像評価等が行われ，これまで行われて いるがん検診と比較してもより優れた精度管理が 行われていると考えられている。秋田県でも「マ ンモグラフィによる乳がん検診の手引き——精度 管理マニュアル に準じて行っており，精度管理 は充分に行われていると考えている。

秋田県総合保健事業団が行っているマンモグラ フィ検診の読影はすべて読影委員会が行ってい る。実際の読影は読影認定 A と B でダブルチェ ックを行っている。現時点では CR で撮影した場 合もハードコピーし , フィルムに落とし読影して いる。比較読影を本格的に開始したのは平成19年 度からである。読影医が比較読影を必要と判断し た場合は 2 年前のフィルムは 1 分以内に取り出せ るようになっている。今回の検討ではマンモグラ フィ検診の要精検率が若干高いがこれは比較読影 がまだ始まったばかりであり，また読影個人の成 績のフィードバックも始まり，徐々に改善される と考えている。他の成績は全国的な成績と遜色は 
ない。精度管理で是非必要な中間期乳癌に関して は, 平成18年度に1例は把握しているが, 弚れ以 外は把握できていない。地域がん登録が徐々に充 実してきているので, 今後は中間期乳癌の把握も 充分に行われる予定である。秋田市の医療機関方 式の要精検率が $20 \%$ を超える施設も数ヶ所あっ た。これも医療機関に自分の位置が分かるように 平成20年度からフィードバックしている。一次読 影では比較読影ができないので要精検率が高いの はやむを得ない面もあるが，20\%以上は高すぎ る。二次読影では比較読影が行われていて，ここ で 2 年前と同じ所見であればカテゴリー 2 以下に しても良いと取り決めをしたので, 少しは改善の 方向に向かうと思われる。

要精検となった受診者に対して，これまで秋田 県総合保健事業団は検診時のマンモグラフィ光の ものは受診者には持参させていなかった。これは フィルムの確実な管理等が理由であるが, 精査機 関でもマンモグラフィを撮影するので , そのため 短期間で 2 度マンモグラフィを撮影していた。総 合保健事業団は医療機関からの貸し出しの要請に は応じている。短期間で 2 度マンモグラフィの撮 影を行わないため, 受診者に貸し出しを要請する か否かを聞いたこともある。しかし頻回の受診を 嫌うため, 貸し出しよりは短期間での 2 度の撮影 を希望する受診者の方が多かった。アナログ撮影 はフィルムがすべてであり，管理上やむを得ない と考えられるが，CR の場合はハードコピーして 乥れを受診者に持っていってもらう方法も考えら れる。今後検討が必要である。

精査機関からの返信は, 診断結果だけではなく 行った検査のすべての情報をいただいている。報 告がない場合は再び問い合わせしているが, 光れ でも最終的に報告のない割合が約15\%程度ある。 最近は医療の崩壊が言われていて, 勤務医はきわ めて多忙な毎日を過ごしている。時間に追われて 精検結果を報告できない場合もある。精検結果の みの報告は事務的なことであり，これは必ずしも 医師が行う必要はない。医師を含めた限りある医 療資源を効率よく運用するために, 各医療機関で
報告システムの変更も考慮すべきである。

検診機関と精査機関とが同じ場所に集まり直接 連携するのに , 秋田県では年 1 回のマンモグラフ イ検診読影検討会を開催している。前年度の検診 症例で教育効果が高いと判断された約50症例を小 グループで約 2 時間かけて討論している。参加人 数は25〜50名である。ここでは読影のカテゴリー 分類が妥当か否かだけではなく，精査機関から報 告された実際の診断名と付き合わせて検討してい る。この際に報告された診断が納得のいくものか も議論し，もし良性と報告されていても悪性の可 能性が高い場合は, 精査機関に再検討をお願いし ている。再検討をお願いした症例の中には最終診 断が乳癌の症例もあつた。この会は毎年 6 月また は 7 月の金曜日に開催しているが, 日常診療が忙 しく全部の精査機関の先生が参加しているわけで はない。关のためここで検討した症例は全例 CD にデータとして保存し，希望があった場合は後日 送付している。

これまで述べたように秋田県の検診機関の精度 管理は小さな問題点はあるものの，光れなりに行 われていると考えられる。吕れに反して精査機関 の精度管理はきわめて難しい。精査機関が備える べき条件の理想はあるが, 実際の臨床がまだ到達 できていないのが現状である。今回の検討で秋田 県の精査機関30施設のうち, マンモグラフィ検診 施設画像認定施設は11医療機関のみであった。マ ンモグラフィの画像診断を行う上で精査機関には 検診機関と同等以上のレベルか望ましいのは明白 である。光して产の11医療機関のうち乳癌学会の 専門医在籍は 4 医療機関, 認定医は 3 医療機関で あった。診断に関しては専門医や認定医が必ずし も優れていると言い切れない面もあるが, 専門医 や認定医のいる施設の方がマンモトームや M RI 等の診断設備が整っている傾向にあると感じられ る。数値にはなかなか表せないが, 精査機関の診 断のレベルの差はあるように考えられた。「がん 対策基本法」では基本的施策として「がんの予防 及び早期発見の推進」だけでなく「がん医療の均 てん化の促進」もうたっている。精査機関の診断 
のレベルの差の解消は重要な問題と考えられる。 その改善には一朝一夕には不可能であり, 行政, 医療関係者の地道な努力が必要である。いずれ精 査機関が備えるべき条件の制定は精度管理の面か らいって必然である。しかし今すぐ精査機関の絞 り込みを行うと専門医や認定医の在籍している病 院に地域差があり，少なくとも秋田県では実情に 合わないと考えられる。現在, 秋田県では乳腺の 専門医を目指す医師が非常に少ない。現時点で一 番重要なのは人材の確保である。乳腺診療の魅力 を後輩に伝え, マンパワーの増大を画して精査機 関の質の向上を目指したい。

まとめ

秋田県のマンモグラフィ検診は精度管理がなさ れ，成績に関しては他県と遜色のない検診が行わ れていた。今後の課題として検診時のマンモグラ フィを精査機関に持参するシステムを作る必要が ある。また精査機関から検診機関への結果報告を 確実に行うため報告システムの変更も考慮すべき である。数値にはなかなか表せないが, 精査機関 の診断のレベルの差はあるように考えられた。精 査機関の精度管理はただでさえ難しいが，秋田県 においては乳腺専門医が少なく早急な改善は望め
ない。今後乳がん検診のさらなる飛躍を目指すた めには, 精査機関の質の向上と検診機関と精査機 関との密接な連携が必要である。

【文 献】

1) 厚生省老健局老人保健課長：「がん予防重点健 康教育及びがん検診実施のための指針」の一部 改正について . 老健第65号通達，2000 3

2 ) 厚生労働省老健局老人保健課長: 「がん予防重 点健康教育及びがん検診実施のための指針」の 一部改正について. 老老発第0427001号通 達, 2004.4

3 ) 鎌田収一, 工藤 保, 西成忍, 他: 秋田県に おける乳がん検診の現状と今後の課題 . 日乳癌 検診学会誌, $15:$ 106-112,2006

4 ) 遠藤登喜子, 森田孝子, 丹羽多恵, 他 : マンモ グラフィ検診の現状と問題点. 乳癌の臨床, 23 : 183-190 2008

5 ) がん対策基本法(平成18年 6 月23日法律第98号)

6 ) がん対策推進基本計画(厚生労働省発表 平成19 年 6 月15日) http : / / www.mhlw.go.jp/ shingi/2007/06/s0615$1 \mathrm{html}$

7 ) 大内憲明 : マンモグラフィによる乳がん検診の 手引き——精度管理マニュアル. 第 3 版増補, 日本医事新報社，東京，2007 


\title{
Current Status and Problems of Breast Cancer Screening in Akita Prefecture, with Special Reference to Cooperation between Facilities for Closed Examination and Those for Primary Screening
}

\author{
Shuichi Kamata ${ }^{12)}$, Takashi Sashi' ${ }^{2)}$, Tamotsu Kudoh ${ }^{2)}$, Masaaki Nakamura ${ }^{2)}$, Yoshihisa Katayose ${ }^{2)}$, \\ Tomomi Yoshioka $^{2)}$, Akira Tsuda ${ }^{2)}$, Koichi Ishiyama ${ }^{2)}$, Masahiro Satoh ${ }^{2)}$, Shinobu Nishinari ${ }^{2)}$
}

D epartment of Surgery, A kita Red C ross $\mathrm{H}_{\text {ospital }}{ }^{1)}$

A kita Prefectural Committee of B reast C ancer Screening ${ }^{2}$

Although the introduction of mammography for breast cancer screening has been slightly delayed in Akita Prefecture, the quality control of mammographic screening carried out by the Akita Foundation for Health Care has recently been maintained at a satisfactory level. In the year of 2007, the breast cancer detection rate, the rate of closed examination, the rate of responders for closed examination, and the positive predictive value were $022 \%, 8.7 \%$, approximately $80 \%$ and $32 \%$, respectively, which were almost the same levels as the national standard. Since women who were recommended to undergo a closed examination did not bring an initial screening mammogram, they underwent mammography again within a short time following the first one. About $15 \%$ of all facilities for closed examination did not report the results. These two points should be amended in the future.

We have held a study meeting for mammography reading once a year at one location in order to maintain good communication between facilities for primary screening and those for closed examination. The materials selected for presentation were about 50 examinee mammograms taken in the previous year which seemed to have educational value. We discussed the validity of the reported diagnoses. One of the selected cases was initially reported as a benign lesion, but the final diagnosis was changed to breast cancer after a detailed examination.

Of a total of 30 facilities for detailed examination in Akita Prefecture, only 11 were the authorized imaging units, among which the specialized doctors authorized by the Japan Breast Cancer Society resided at four institutions and mammography-qualified doctors resided at three. Although it was difficult to derive a distinct figure, facilities for detailed examination appeared to have individually different levels of ability. In the future, the standard that a facility for detailed examination should fulfill must be determined from the standpoint of quality control. At least in Akita Prefecture, however, urgent limitation of facilities for detailed examination to only authorized institutions seems to be impractical. In order to further promote breast cancer screening, we must improve both the quality of facilities for detailed examination and communication between facilities for primary screening and those for closed examination.

Key words : quality control, Akita Prefecture, mammography screening, facilities for closed examination, cooperation. 